\title{
50 Formula Approaches for Market Access Negotiations
}

\author{
Joseph Francois 1,2 \\ Will Martin ${ }^{3}$
}

${ }^{\prime}$ Faculty of Economics, Erasmus University Rotterdam, and Tinbergen Institute, ${ }^{2}$ CEPR, ${ }^{3}$ World Bank. 
Tinbergen Institute

The Tinbergen Institute is the institute for economic research of the Erasmus Universiteit Rotterdam, Universiteit van Amsterdam and

Vrije Universiteit Amsterdam.

Tinbergen I nstitute Amsterdam

Keizersgracht 482

1017 EG Amsterdam

The Netherlands

Tel.: +31.(0)20.5513500

Fax: $\quad+31 .(0) 20.5513555$

Tinbergen Institute Rotterdam

Burg. Oudlaan 50

3062 PA Rotterdam

The Netherlands

Tel.: $\quad+31 .(0) 10.4088900$

Fax: $\quad+31 .(0) 10.4089031$

Most TI discussion papers can be downloaded at

http://www.tinbergen.nl 


\title{
Formula Approaches for Market Access Negotiations*
}

\author{
Joseph Francois \\ Tinbergen Institute and CEPR \\ and \\ Will Martin \\ World Bank
}

November 18, 2002

\begin{abstract}
*This paper reflects the personal views of the authors only and not those of any institution with which they are affiliated. We would like to thank numerous friends and colleagues, and particularly Elwyn Grainger-Jones, Bernard Hoekman, Richard Newfarmer, Marcelo Olarreaga, Ernie Preeg and Alan Winters, for valuable comments on earlier drafts. All remaining errors are, of course, our own. This paper is part of a broader World Bank research effort to identify ways that market access might be enhanced under the Doha Development Agenda.
\end{abstract}

Correspondence Addresses: J.F. Francois, Burg Oudlaan 50-H8-18, Erasmus University Rotterdam, 3000DR Rotterdam NL francois@,few.eur.nl; Will Martin, World Bank, 1818 H St NW, Washington DC 20433, USA. wmartin1@worldbank.org 


\title{
Formula Approaches for Market Access Negotiations
}

\begin{abstract}
Most of the large tariff reductions achieved in multilateral trade negotiations have involved tariff-cutting formulas such as the "Swiss" formula. However, wide variations in initial tariff rates between active participants call for new approaches under the Doha Development Agenda. This paper surveys a range of formula options and examines both targeted and flexible applications of the Swiss formula that target tariff escalation and peaks, and would allow policy makers to directly target how far they will move towards free trade, while providing some flexibility for trading off reductions in peak tariffs against reductions in lower-tariff sectors.
\end{abstract}

Keywords: market access, tariff formulas, WTO

JEL codes: F13, F1

\section{INTRODUCTION}

There is an urgent need for WTO members to identify a set of feasible and effective modalities for establishing market access commitments in current WTO negotiations. Otherwise, there is a very real danger that the Doha Development Agenda negotiations will fail to make progress in expanding market access, particularly for developing countries. We stress two widely-agreed objectives for such modalities: (i) they should ensure a balanced exchange of concessions, and (ii) they should reduce relatively high barriers by more than lower barriers - both to increase the size of the market access concessions exchanged, and to increase the economic benefits to importing countries. While the trade agenda has expanded considerably beyond the GATT focus on tariff reductions, there is widespread agreement that improvements in market access conditions remain one of the most important ways that WTO negotiations can contribute to economic development (Hoekman 2002).

One approach frequently adopted in past trade negotiations is the development of a formula to determine the commitments made by each country. If the right formula can be found, this approach increases the likelihood of success relative to options involving more discretion in determining protection in individual sectors. This greater probability of success reflects the immediate creation of a balanced package involving gains to exporters as well as costs to import-substituting firms, and a reduction in the ability of individual firms and sectors to lobby for the retention of protection that benefits them at the expense of the broader social interest. Greater success of formulabased approaches has been evident not just at the WTO, but in regional arrangements such as the ASEAN Free Trade Area (Fukase and Martin 2001), which began with an unsuccessful discretionary approach and succeeded using a formula approach that encouraged offers of market access. Nor are formula approaches relevant only for trade in goods. Low and Mattoo (2003) have advocated applying formula-based approaches in the Doha Agenda negotiations on Services. 
The initial approach to tariff negotiations at GATT was the request-and-offer procedure under which members negotiate bilateral market access concessions, and subsequently extend them to all members. Using this procedure, GATT members were able to reduce average tariffs by around 20 percent in the initial, Geneva Round (1947) of negotiations (Baldwin 1987). However, emphasis on this approach produced disappointingly slow progress in the four following rounds of negotiations ${ }^{1}$. Only with the introduction of a comprehensive formula approach during the Kennedy Round (1963-7) was it again possible to achieve substantial cuts in protection-35 percent as against an average of 2.5 percent in the previous four negotiations. The next round, the Tokyo Round (1974-9), used a more sophisticated formula, the socalled Swiss formula, and achieved a 30 percent reduction in average tariffs. The Uruguay Round (1986-94) used a simpler approach involving setting broad tariffreduction goals such as a 30 percent average reduction on industrial products, but leaving the distribution of the cut across sectors up to negotiations between trading partners. This approach was successful in achieving substantial tariff reductions. However, it was generally not successful in achieving higher proportional cuts in higher tariff rates and hence in sharply reducing tariff escalation. Abreu (1996, p64) observes that items with higher tariff rates typically had smaller proportional cuts.

The Uruguay Round agreement on agriculture involved a range of formula-type elements, including average cuts in tariffs; a minimum cut in each tariff line; formulas for establishing bindings where protection had been provided by non-tariff barriers; and ceiling binding options. The resulting outcome frequently involved large tariff cuts in small tariffs (Hathaway and Ingco 1996), and extremely high tariff bindings that are creating difficulties for Doha Development Agenda negotiators. It highlights the dangers of approaches that focus on the average cut in tariffs, rather than achieving cuts in the average tariff, and the risks associated with leaving excessive discretion in the approaches used to reduce protection.

Part of the reduction in Uruguay Round tariffs was brought about through zero-forzero tariff reductions in which tariffs on groups of products were reduced to zero-an approach that succeeded in the Information Technology Agreement (ITA), but failed in the ITA (II) and the abortive proposals for Early Voluntary Sectoral Liberalization. As Panagariya (2002) notes, it seems likely that the sectors targeted under this approach will generally be those where tariff rates are initially low, and those of particular interest to the major industrial powers, rather than high protection rates and those of greatest concern to poorer developing countries.

The potential benefits from use of a formula approach are large. If a suitable topsdown formula can be identified and implemented, we can be relatively sure that it will lead to a global welfare gain, since the social costs of tariffs generally rise more rapidly than the rates themselves ${ }^{2}$ By contrast, approaches that focus on reducing relatively low, "nuisance", tariffs face the risk of reducing economic welfare and tariff revenues by diverting imports away from higher-tariff items (see Martin 1997). Even request-and-offer procedures can result in a focus on reducing tariffs in relatively lightly-protected, "easy" sectors, rather than the sectors with the high protection rates that generate the greatest social costs.

\footnotetext{
${ }^{1}$ A simple formula was first tried out in the Dillon Round (Ernest Preeg, personal communication).

${ }^{2}$ See Vousden 1990, p233. López and Panagariya (1992) point out that the presence of non-produced intermediates weakens this general proposition.
} 
Formula approaches also have the potential to contribute to a more balanced package of concessions between developed and developing countries. They would likely require reductions in the relatively high tariffs faced by smaller and poorer countries (Hoekman, Ng and Olarreaga 2002), who find it difficult to make progress in requestand-offer negotiations because of the small size of their markets. They are also likely to reduce protection in the more highly protected sectors in developing countries, increasing efficiency in these countries, and disproportionately improving the market access opportunities of developing countries by stimulating south-south trade (Hertel and Martin 2001).

The challenge for participants in identifying the best approach to use is complicated by the sharp differences between the current situation and the beginning point in earlier rounds of negotiations. One important difference is the much wider dispersion in the initial tariff regimes of active WTO participants. A second is the frequentlywide gaps between applied rates and tariff bindings resulting from the use of high bindings in the Uruguay Round, and from the wave of applied rate reductions that has swept the developing countries in recent years, reducing average tariff rates to a fraction of their level in the 1980s (World Bank 2001). Another important difference is the larger number of active participants in the negotiations, which makes classic request-and-offer procedures more difficult. When formula approaches were applied in the Kennedy and Tokyo Rounds, the number of participants was relatively small and the negotiations - which focused on tariffs on industrial products in developed countries - involved tariff regimes that were broadly similar in their average levels and distribution. By the time a sharply tops-down formula was applied in the Tokyo Round, the active participants (industrial countries) had been through six previous rounds of negotiations on the same products. By contrast, the current negotiations are only the second for agriculture, and the second involving active participation by large numbers of developing countries in exchanges of market access concessions for industrial products (Martin and Winters 1996).

The increase in the number of active participants in the negotiations increases the difficulties involved in request-and-offer type procedures, and increases the attraction of formula approaches. However, the wider dispersion of initial tariffs, and the gaps between bindings and applied rates, may create challenges and a need for flexibility in formula approaches not encountered in the Tokyo Round. A key purpose of this paper is to try to identify potential solutions that negotiators might use to deal with these problems.

Strict application of a tops-down formula would undoubtedly create political resistance in virtually all countries, but would produce correspondingly large benefits in terms of market access, which might generate the political support needed to complete the negotiations. One of the interesting features of the wave of across-theboard liberalization undertaken in developing countries, and in liberalizing industrial countries like Australia and New Zealand, during recent years has been the much more muted political opposition to broad-based liberalization than to sector-by-sector approaches. Partly, this reflects the fact that, with general liberalization, the costs of each industry are lowered at the same time as their own output protection is lowered. We would speculate that another part is due to the special pleading of a wide range of sectors being less effective when a broad reform to improve the competitiveness of 
the economy is being undertaken, than when specific sectors are being singled out for reductions in protection — or are actively seeking protection.

This paper is organized as follows. In Section 2, we first provide some detail on the current market access landscape. This highlights important issues related to tariff peaks, unbound tariffs, and gaps between bound and applied rates. Collectively, these issues will be important determinants of success for any approach to defining market access concessions. In Section 3, we then consider some formula-based approaches. In Section 4, we develop the concept of "flexible formula" approaches. These approaches potentially include built-in elements of credit for autonomous liberalization, and target tariff escalation and peaks, yet also allows some flexibility for trading off reduction in peak tariffs (reflecting politically sensitive sectors) against reductions in low-tariff sectors. In Section 5, we consider some of the design issues associated with the use of a flexible formula approach. For illustration, and to assess the quantitative implications of some plausible approaches, we work with an initial sample of 3 industrial countries and 3 developing countries in Section 6 . We conclude in Section 7.

\section{A QuiCK TOUR OF THE MARKet ACCESS LANDSCAPE}

Tariff negotiations in the multilateral trading system have generally been based on tariff bindings, or schedules of concessions tabled under GATT rules, and the coverage and level of these bindings is an important element of the initial conditions for the negotiations. Table 1 provides information on the share of industrial-product tariffs (on a trade-weighted basis) that remains either unbound or bound above applied rates. While tariffs in the OECD (and Latin America) are generally bound, many Asian and African economy tariffs remain unbound despite more than a four-fold increase in the coverage of developing-country tariff bindings in the Uruguay Round (Abreu 1996). For almost all developing countries, existing bindings are, on average, well above applied rates, reflecting a combination of relatively high initial bindings, and the subsequent wave of reductions in applied rates. (See Blackhurst et al 1996, Francois 2001).

In addition to general Uruguay Round commitments, there have also been efforts for sector-based commitments to implement zero tariffs (called "zero-for-zero"). This is reflected in the next-to-last column of Table 1. As a result of zero-for-zero efforts, OECD economies have between roughly $10 \%$ and $30 \%$ of tariff lines bound at zero percent. Most developing countries have opted out of this process. Zero-for-zero increased developed country duty-free imports to $43 \%$ of total imports (Laird 1998). The process itself ground to a halt after the initial Information Technology Agreement (ITA). This seems to have been for two reasons: (i) the sectors in which OECD economies could easily reach agreement had already been included, and (ii) those sectors remaining involve North-South issues not susceptible to this approach. In other words, the cherries have been picked, leaving us with the hard nuts.

With the implementation of Uruguay Round commitments, average ad valorem tariffs in the industrial countries generally are around 3 percent. This is reflected in the first columns of Table 2. However, there are important exceptions. One of these is textiles and clothing, where the average rate is roughly three times this average. This is reflected in the standard deviation and maximum tariff columns. With full 
implementation of current commitments, we estimate a simple average industrial tariff in the United States of 3.2 percent, a standard deviation of 4.3, and a maximum tariff of 37.5 percent. The European Union has a higher average, but less dispersion. We estimate an EU average of 3.7 percent, a standard deviation of 3.6 percent, and a maximum tariff of 17 percent.

For the developing countries in Table 1, average industrial tariffs range from a low of 3 to 4 percent to a high of more than 20 percent. Table 2 presents detailed data for three developing countries: Brazil, India, and Thailand. These countries span the spectrum of developing country bindings as reflected in Table 1. Brazil's tariffs are all bound, though the average rate for industrial products is 14.9 percentage points above the current applied rate. We refer to this gap below as "binding overhang." India and Thailand's tariffs are partially covered by bindings, again with significant binding overhang.

As in the case of industrial tariffs, the stage for any future agriculture negotiations was largely set by the Uruguay Round outcome-- this time by the Uruguay Round Agreement on Agriculture (URAA). One key difference from industrial products is that essentially all agricultural tariffs are bound. However, in both industrial and developing countries, there is a large degree of binding overhang resulting from "dirty tariffication" or the use of "ceiling bindings" (Hathaway and Ingco 1996). The next round of agricultural negotiations was scheduled in the URAA, while the negotiating parameters (tariffs, tariff-rate-quota levels, subsidy commitments, etc.) must also be viewed in the context of the schedules of URAA commitments. The system that has emerged is complex and similar to arrangements in the textile and clothing sectors, featuring a mix of bilaterally allocated tariff-rate-quotas (with associated quota rents) and tariffs. Viewed in conjunction with industrial protection, the basic pattern is that the industrial countries protect agriculture and processed food, while protection in developing countries is more balanced (though also higher overall) in its focus on food and non-food manufactured goods. Any formula approach to negotiating market access in agriculture will have to deal with both tariff bindings and quantity commitments.

\section{A PRIMER ON TARIFF REDUCTION FORMULAS}

A range of different tariff-cutting formulas has been considered or implemented under GATT and regional trade arrangements. Stern (1976), Laird (1998), Laird and Yeats (1987) and Panagariya (2002) all discuss a number of potential approaches. The first is a simple proportional cut:

$$
t_{1}=c \cdot t_{0}
$$

Where $t_{0}$ is the initial tariff (which may be an MFN applied rate; a preferential rate in a regional negotiation; or a tariff binding in the WTO context), $t_{l}$ the rate after application of the formula and $c$ is the constant proportion of their original rate to which tariffs are to be reduced.

After years of intense diplomatic negotiations on the difficult technical subject of situations where there were disparities in countries' initial tariff rates (Preeg 1970), a 
50 percent proportional cut formula was used in the Kennedy Round (1963-67). Some products were, in fact, exempted from this approach and permitted smaller tariff reductions on the grounds of their sensitivity. Since the products exempted had much higher than average tariffs, these exemptions substantially reduced the cut in the overall average tariff. Baldwin (1987, p43) estimates that, despite these exceptions, the reduction in average tariffs on industrial products was 35 percent. This compared extremely favorably with the average of 2.5 percent he estimated was achieved in the second through the fifth rounds of GATT tariff negotiations, generally conducted under the request-and-offer approach.

While equation (1) brings about a large reduction in the absolute value of higher tariffs, it does not have the desirable feature of bringing about larger proportional reductions in the highest tariffs. The ratio of the post-round tariff to the pre-round tariff is, in fact, equal for all tariff rates. This is shown by the fact that, for all tariff rates:

$$
\frac{t_{1}}{t_{0}}=c
$$

Equally important, a proportional approach means market access concessions are higher for highly protected products than for less-protected products. As we show in the Appendix, the proportional reduction in domestic market prices increases with the initial tariff rate, implying that increases in market access will tend to be greater on products with higher initial tariffs.

An alternative proposal considered in the Tokyo Round negotiations was a more general linear reduction approach:

$$
t_{1}=d+f \cdot t_{0}
$$

where $d$ is a positive constant and $f$ is a number between zero and one. As with equation (1), this formula may be written with tariffs in percentage or proportional terms by making an appropriate adjustment to the parameter $d$. This approach would generally lead to larger percentage reductions in higher tariff rates, as is shown in the Appendix. As is also shown in the Appendix, the reduction in domestic prices under this general linear reduction approach will again generally rise with the initial tariff rate.

Formula (3) suffers, however, from a potentially serious problem where initial tariff rates are low. If the parameter $d$ exceeds zero-which it must to yield larger percentage reductions in higher rates - this formula will lead to increases in lower rates. While there may be a case for some such increases in tariffs as a way of reducing the variation in tariff rates and hence the cost of protection (Anderson 1999), such increases in tariffs do not sit easily with the trade liberalizing raison d'etre of the WTO. As a means of dealing with this problem, the proponents of this approach during the Tokyo Round advocated that it be applied only for tariffs greater than 5 percent (Laird and Yeats 1987).

Like the simple proportional cut, the general linear approach yields greater market access concessions for products with high tariffs than for products with low ones. A 
third potential formula considered in the Tokyo Round involved taking the square of the tariff rate from the initial tariff rate. To obtain sufficient tariff reductions, it was proposed that this operation be undertaken four times.

The fourth candidate formula--and the one finally accepted in the Tokyo Round after a great deal of negotiation-- was the Swiss formula:

$$
t_{1}=\frac{a \cdot t_{0}}{a+t_{0}}
$$

where $a$ is a positive tariff rate that becomes a ceiling on tariff rates. If tariffs are expressed in proportional terms, then the Tokyo Round value of this parameter was in the range 0.14 to 0.16 . For tariffs in percentage terms, the corresponding parameter values are 14 to 16 .

The Swiss formula has a number of desirable features for tariff negotiations. It is simple, with a single application of the formula being sufficient to bring about the required transformation of tariff rates. It is particularly effective in reducing peak tariffs, since even the very highest tariffs are reduced below the value $a$. Finally, it has the desirable feature of reducing higher tariff rates by more, in both absolute and relative terms, than lower tariff rates. This feature is important both for overall economic efficiency, and for preserving tariff revenues for any given reduction in the average tariff.

The progressive nature of the reductions under the Swiss formula can be shown by the ratio of the new to the old tariff, which we show in the Appendix falls as $t_{0}$ increases.:

Also as shown in the Appendix, the reduction in domestic prices with the Swiss formula is higher for higher tariff rates, and the rate of reduction increases with the initial tariff rate. Hence, increases in market access are greatest for the most heavily protected products.

A few examples are useful for obtaining a feel for the nature of the relationship between initial and final tariffs under the Swiss formula. For an extremely small initial tariff, say one tenth of one percent, $a /\left(a+t_{0}\right)$ in equation (8) is essentially one, implying no reduction in the tariff. For an initial tariff rate of $a$, the final tariff rates is a half of $a$, implying a 50 percent reduction from the initial tariff. For a very high initial tariff, $t_{0} /\left(a+t_{0}\right)$ is effectively one and the tariff rate is essentially reduced to $a$.

A very stylized comparison of the proportional tariff cut of 0.5 used in the Kennedy Round with a Swiss Formula using the parameter 0.16 from the Tokyo Round is shown in Figure 1. The diagram shows that the cuts in low tariffs are smaller using the Swiss formula than using the proportional cut formula, but that the cuts for tariffs above 0.16 were larger using the Swiss formula. While the figure does not make this clear, no tariff would remain above 0.16 following application of this formula. 
Figure 1. Impacts of a Proportional and a Swiss Formula for Tariff Cutting

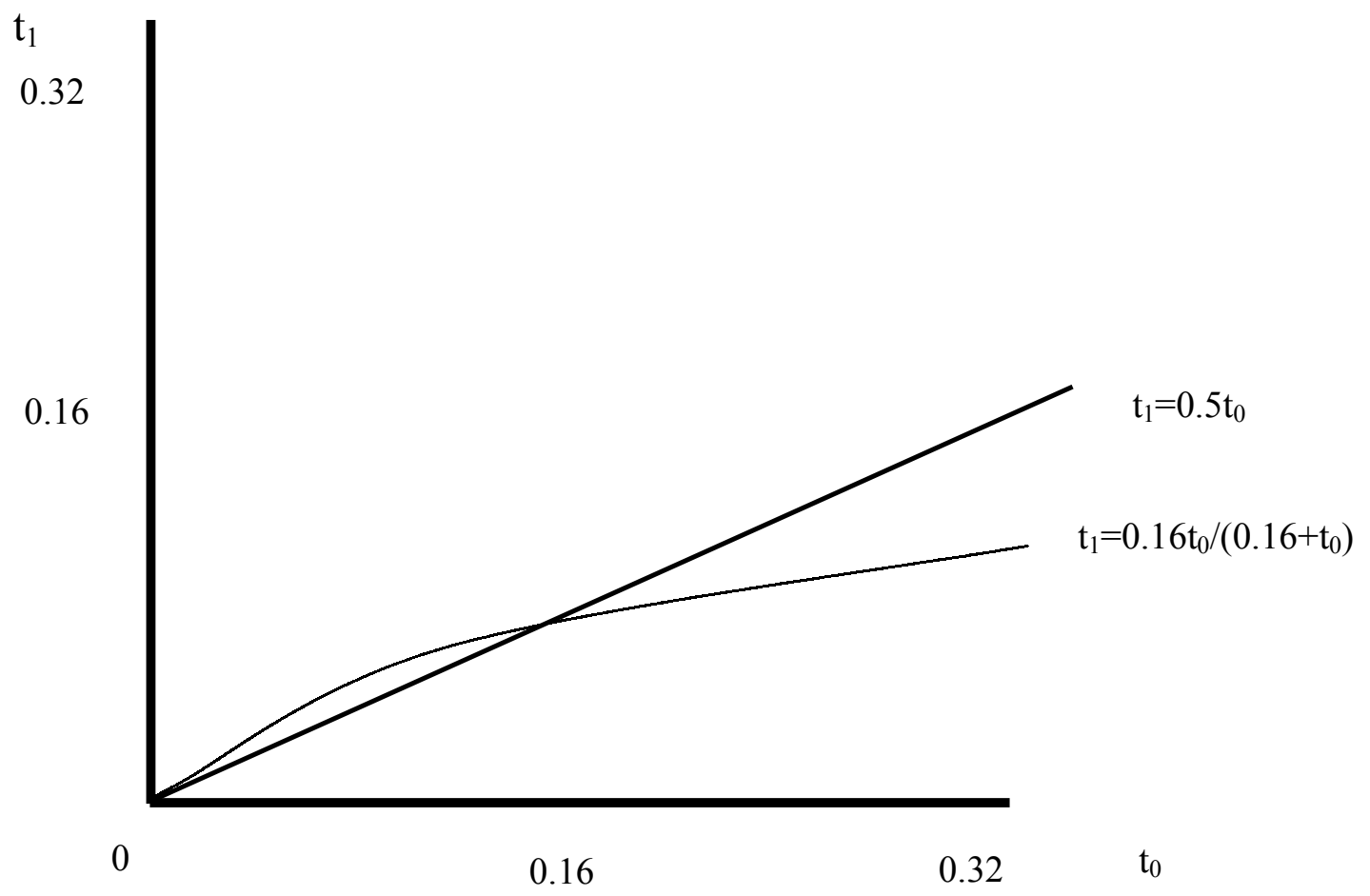

A number of other formula-type approaches to structuring market access expansion have been proposed. Josling and Rae (forthcoming) consider alternatives including reduction of bound rates to applied rates; the introduction of ceilings on tariffs; and the use of "cocktail" approaches involving use of different formulas, such as reductions to a ceiling rate, proportional cuts and Swiss-formula cuts over different ranges of tariffs. Hoekman and Olarreaga (2002) examine the introduction of a limit on the ratio of the highest tariffs to the average as a means of dealing with tariff peaks.

\section{INTRODUCING SOME FLEXIBILITY TO FORMULA CUTS}

There are good reasons to question whether a pure Swiss formula, with a common upper limit of around 0.15 as used in the Tokyo Round, would provide sufficiently flexibility for all WTO members to reach agreement on tariff reductions under the Doha Development Agenda. A key difference from the Tokyo Round is the wide variation in tariffs between active participants in the negotiations. In fact, it seems very possible that the Swiss formula was not sufficiently flexible in the past either. Even though the participants in the Tokyo had been through six previous rounds of negotiations on the same products, large numbers of products with relatively high tariffs were excluded from the formula in the Tokyo Round and treated instead on a case-by-case basis. Unfortunately, many of these products were items such as agricultural products, textiles and clothing that are of particular interest to developing countries, which were not active participants in the exchange of market access 
concessions at that point. The exception of relatively high rates from the discipline of the formula approach contributed to the current problem of tariff peaks in the industrial countries. (See the peaks in Table 2).

Hoekman and Olarreaga (2002) note that peak applied tariffs in the industrial countries are now around 50 times as high as the average rate. This contrasts with a ratio of five in the developing countries of Sub-Saharan Africa, six in Latin America, seven in the Middle East and North Africa, nine in South Asia, and 28 in East Asia. Clearly, the widespread use in developing country trade reforms of tops-down liberalization approaches noted by López and Panagariya (1992) has had a profound impact on the distribution of developing country tariffs. The combination of quite large differences in the means and the variances of tariffs across countries seems likely to create a need for a formula that could encompass the entire distribution of tariff rates without creating too much pressure for exceptions and special cases.

One possible approach to dealing with this would involve application of a Swiss-type tariff reduction, guided by targeted reductions in the average tariff rather than a common Swiss formula parameter $a$. In effect, this combines the targeting of the distribution of tariffs under the pure Swiss formula with the targeting of a reduction in the average tariff. This targeted formula approach takes care of the "one size fits all" problem of a common $a$ parameter. However, it still leaves the problem of flexibility. To combat the flexibility problem, one can generalize the Swiss formula to allow more flexibility in dealing with different tariff profiles. Under this flexible formula approach, the idea is to maintain the key attributes of the Swiss formula - its use of a uniform maximum below which all peak tariffs must be reduced and its progressive feature of cutting high tariffs by more than low tariffs - while allowing greater flexibility of approach to accommodate different preferences over tariff maxima and rates of reduction. Might introducing additional flexibility result in a modified Swiss formula that would allow a compromise to be reached, while retaining the advantages of a formula approach?

One way to provide some additional flexibility is to modify the original Swiss formula by introducing an additional parameter, $b$, into equation (5) to obtain:

$$
t_{1}=\frac{a \cdot t_{0}}{a \cdot b+t_{0}}=\frac{1}{a^{-1}+b \cdot t_{0}^{-1}}
$$

We call parameter $b$ a flexibility parameter as it allows the shape of the relationship between the initial and final tariffs to change ${ }^{3}$. As can be seen from the second term in equation (5), the original Swiss formula is a special case of equation (5), with $b=1$. As will become evident, the impact of tariff reductions on peak tariffs can be softened by adjustments to the a parameter, while compensating trading partners through reductions in lower tariffs sufficient to achieve a target reduction in the average. As $b$ increases, the formula tends to increase the reduction in the lower tariffs, allowing for higher maximum rates with the same target reduction in the average tariff. Clearly, there is an entire family of Swiss formulas, which differ as a consequence of differences in the $b$ values ${ }^{4}$. If we hold the reduction in the average tariff constant,

\footnotetext{
${ }^{3}$ The first expression in (7) shows its similarity to the original Swiss formula. The second shows the source of the asymptotic feature of the equation-division by a rectangular hyperbola in the tariff rate. ${ }^{4}$ This formula has also been characterized as the Swiss-Army-knife approach to tariff reduction.
} 
then as $b$ rises from 1 , the line showing the new tariff changes from the original Swiss formula curve in Figure 1 closer and closer to the linear reduction curve, providing potentially much greater flexibility to negotiators who had, hitherto, to choose one or the other approach.

To avoid potential problems with formulas that increase the value of tariffs, the flexibility parameter, $b$, should be one or above. This extended Swiss formula retains the key feature of the original Swiss formula that all tariffs are reduced below a ceiling given by $a$. Further, it retains the progressive reduction feature that higher tariffs are cut by more than lower tariffs. In this case, $t_{1} / t_{0}$ is given by:

$$
\frac{t_{1}}{t_{0}}=\frac{a}{a \cdot b+t_{0}}
$$

which confirms that reductions in higher tariffs will be larger than those on lower tariffs.

If we start with a targeted reduction in the average tariff, then the extension of the Swiss formula in equation (5) widens the range over which a formula approach might potentially be used. For example, choice of a $b$ value of 1.5 , rather than 1.0 in equation (5), would reduce tariff rates below the maximum more rapidly than would have been the case with the original Swiss formula. Essentially, choosing a higher maximum while achieving the same percentage reduction in its average tariff would require a country to undertake bigger reductions in its relatively low tariff rates, while still preserving the progressive tendency of the Swiss formula to cut higher tariffs by at least the same proportion as lower rates.

As will be developed below, the parameter $a$ in any Swiss formula cant be chosen to yield a given ceiling tariff rate, or to achieve a given percentage cut in tariffs. Figure 2 illustrates, for an example with tariffs ranging from $0 \%$ to $90 \%$, the percentage reduction in each tariff rate necessary, given a target of a $50 \%$ reduction in the average tariff. As shown, there is some scope for trading off cuts in higher tariffs with cuts in lower tariffs through adjustments to the compensation parameter. The degree of actual flexibility depends on the underlying tariff schedule. One critical point illustrated is that, in the extreme, all high-end tariffs must be reduced by at least the amount targeted for the average, implying that the limit of the flexibility allowed by the modified Swiss formula is a linear reduction formula.

\footnotetext{
${ }^{5}$ Spreadsheets of the examples found in this paper are available from the authors upon request.
} 
Figure 2. Flexibility and Swiss Formula-Based Tariff Reductions

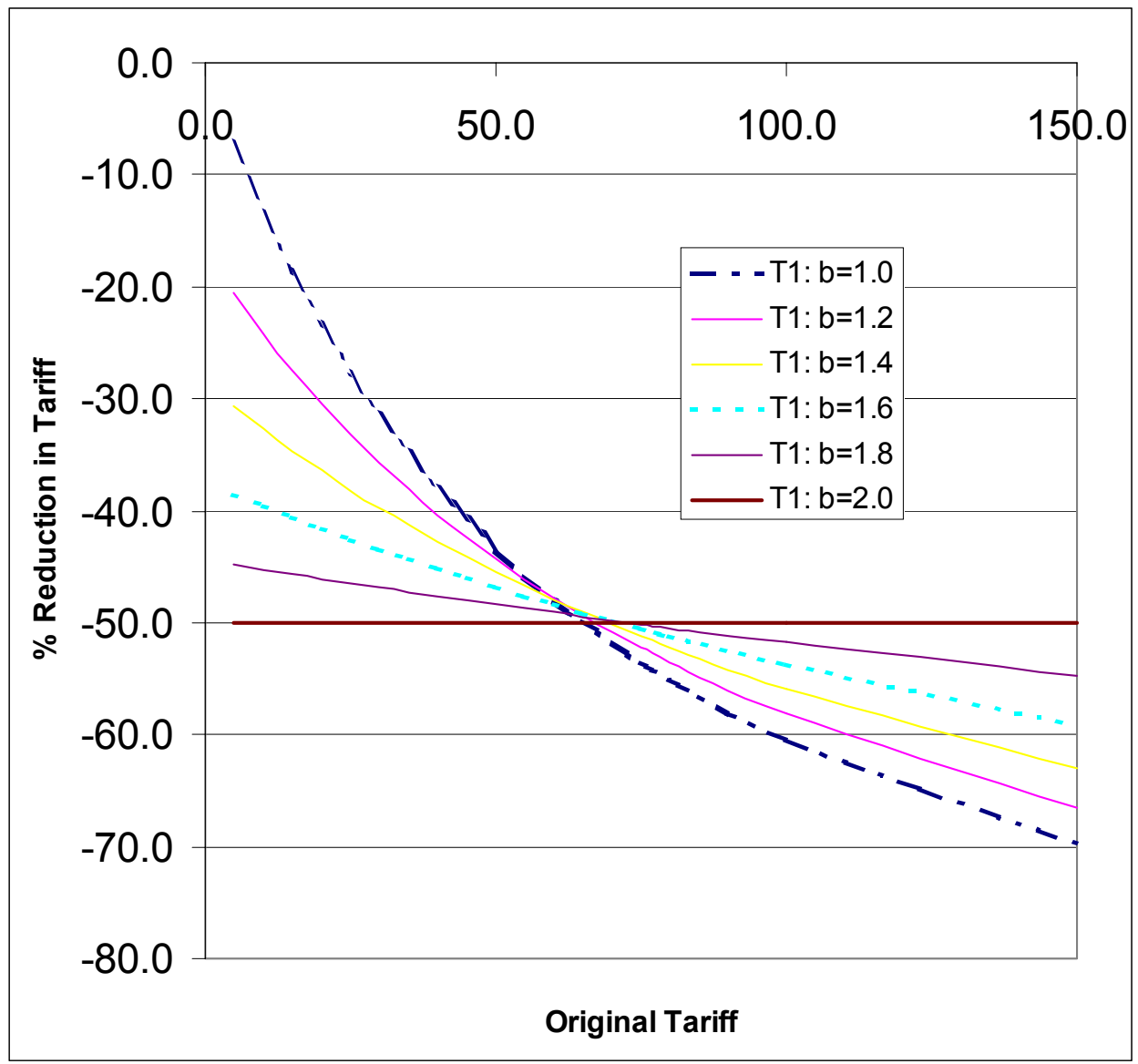

There is a limit to the flexibility we can obtain using the compensation parameter. As we raise $b$, we are substituting larger cuts in smaller tariffs for smaller cuts in higher tariffs. Beyond some point, it becomes infeasible to meet the required reduction in average tariffs. Technically, when we apply equation (5), the parameter combination that allows for meeting the reduction in the average, with the smallest possible cuts in high tariffs, is the limiting value of $b$ when $a \rightarrow \infty$, given the constraint of a reduction in the average. To find this value for any given targeted tariff cut, we can rearrange equation (5) as

$$
\frac{t_{1}-t_{0}}{t_{0}}=\frac{1}{b+t_{0} \cdot a^{-1}}-1=m
$$

where $m$ is the depth of cut, represented by a number such as -0.5 for a 50 percent cut in average tariffs, under the limiting case. The limit of $b$, given the required proportional reduction in the average, $\bar{m}$, will then be:

$$
\left.\frac{\lim }{a \rightarrow \infty} b\right|_{\text {reduction in mean }=\bar{m}}=\frac{1}{(1+\bar{m})}
$$


This implies that $b=2$ at the limit for a reduction in the average of $m=-50 \%$, and $b=1.428$ for $m=-30 \%$. Given the constraints of the formula approach, if we do not reduce tariffs above the average by at least the target reduction in the average, we are otherwise unable to meet our target for the cut in the average. In other words, adopting a combined targeted and flexible Swiss formula approach guarantees that peak rates will be cut by at least the cut in the average, even with flexibility.

Of course, using the flexibility inherent in the flexible Swiss formula to move from the original Swiss formula outcome with the same average cut in tariffs has economic costs in economic efficiency and tariff revenues. Raising the tariffs on goods already subject to high tariffs reduces the volumes of these imports, which have the highest value in the domestic market relative to their cost on world markets. It also tends to reduce tariff revenues more for any given reduction in average tariffs, since the volumes of high-tariff imports decline relative to those of low-tariff imports. From the exporters' point of view, it implies relatively small reductions in the imports with the greatest potential to grow as a result of liberalization. To the greatest extent possible, the use of this flexibility should therefore be avoided. However, some structured use of such flexibility may help counter political economy considerations that can drive a poorly-disciplined retreat to exceptions and other discretionary approaches.

As we have seen, the flexibility in the use of a Swiss Formula approach can yield a number of alternatives, including the original Swiss Formula and a proportional cut in tariffs. It is also consistent with proposals to move to zero tariffs (see, for example, Preeg 2002) - that could be achieved by setting the $a$ parameter to zero. A key issue is how it might be implemented given the market access landscape outlined above.

\section{Semantics Matter}

Many options for implementing formula approaches in a multilateral trade negotiation are possible, and we consider only a few new ones in this paper. However, we hope that the process of examining these options might help stimulate ideas on the wider range of possibilities.

\subsection{Average cuts or cuts in the average?}

One fundamental parameter in the negotiations is the objective of tariff reduction to be specified. Should it be specified in terms of a percentage reduction in average tariffs (simple or weighted); or in terms of an average tariff cut; or in terms of a ceiling tariff like the 0.15 used in the Swiss formula during the Tokyo Round; or as an average reduction in the price of imports ${ }^{6}$, or as a cut in tariffs weighted by the volume of imports?

The difference between an average cut in tariffs and a cut in the average tariff seems small, but is actually fundamental. While the percentage reduction in the average tariff is an appealing organizing objective in that it is readily understood as measuring progress from the initial regime towards complete free trade, an average cut in tariffs seems to have the unfortunate political-economic effect of encouraging large

\footnotetext{
${ }^{6}$ This measure, defined for a small country by $\Delta \mathrm{t} /(1+\mathrm{t})$, where $\Delta \mathrm{t}$ is the change in the tariff rate, is an important determinant of the increase in market access resulting from a negotiation.
} 
percentage cuts in low tariff-rate commodities, as was evident in the Uruguay Round agreement on agriculture (Hathaway and Ingco 1996). Any approach with this feature may well reduce both tariff revenue and economic welfare. While other approaches have some merit, and measures such as the change in the price of imports should certainly be used in evaluating the consequences of any proposed formula, we focus initially on the familiar GATT negotiating objective of a percentage cut in the average tariff rate-a measure that has the intuitively-appealing feature of indicating the progress from the current situation to complete free trade $^{7}$.

If a reduction in the average (50 percent for our example) were set as a goal, the $a$ parameter in the Swiss formula needed to bring this about would be determined by the initial distribution of tariffs in each country. During the Tokyo Round, evaluating the link between a given tariff reduction goal and the needed value of the $a$ parameter would have been relatively difficult, and this may have contributed to the decision to set the $a$ parameter rather than a goal in terms of a percentage cut in the average tariff. Now, finding the Swiss formula parameter that satisfies the requirement of a given reduction in average tariffs is easy for anyone with access to a spreadsheet program like Microsoft EXCEL and could potentially be automated for inclusion in trade and tariff analytical software like the WITS system ${ }^{8}$. Once a target reduction in the average tariff has been set, a program like EXCEL can be used to calculate the $a$ parameter value that will achieve this goal with the basic Swiss formula.

If countries were unable to accept the results from the initial application of the Swiss formula, they might be given the option of choosing a higher maximum and a different value of the $b$ parameter to achieve the same reduction in average tariffs without such drastic reductions in peak tariffs. It is in this sense that the $b$ parameter then serves as a compensation parameter, facilitating some maintenance of tariff peaks at the cost of deeper cuts on lower tariffs. Again, a simple program like Microsoft EXCEL's Solver can be used to find the combinations of $a$ and $b$ consistent with the targeted reduction in average tariffs.

As previously noted, the Swiss formula approach incorporates a tariff ceiling, but also provides a logical basis for making reductions in all tariffs below the ceiling without introducing discontinuities that are difficult to justify either analytically or to the special interests adversely affected by them. If the flexible Swiss formula approach were adopted, then either a tariff ceiling or a reduction in the average tariff could be chosen, but not both. If the ceiling rate is to be varied on the basis of special sensitivities in the tariff-peak sectors, then there seems a good case to require that a reduction in the average tariff be maintained even while the curvature of the Swiss formula is varied through changes in the $b$ parameter. In fact, policy makers might wish to introduce a penalty, by requiring a higher average cut in tariffs, when use is made of greater flexibility.

\footnotetext{
${ }^{7}$ Assuming all protection is provided through tariffs.

${ }^{8}$ The World Integrated Trade Solutions (WITS) system is being developed by the World Bank in conjunction with the TRAINS database of UNCTAD, and allows analysis using a range of databases, including the WTO's Integrated Database (IDB) and Consolidated Tariff Schedules (CTS). Spreadsheet examples of the formula applications in this paper are available on request.
} 


\subsection{How to choose the base rate}

A key issue in implementing any formula-based approach is the base rate to which the formula should be applied. In a regional negotiation context, this rate will generally be the preferential applied rate. Countries using a formula approach to reform their own tariffs would generally use the applied MFN rate as the base. Traditional GATT practice has been to focus on the bound rates contained in countries' schedules of concession. This has the important advantage of creating no disincentive for undertaking unilateral reductions in applied rates of the type that have so sharply reduced protection in developing countries during the past 20 years (World Bank 2001). In addition, this approach might be viewed as providing credit for unilateral liberalization in the sense that a prior unilateral reduction of applied rates reduces one-for-one the cut in applied rates required in a subsequent negotiation. Negotiations that focused on historical applied rates, say from the end of the Uruguay Round, would also have these two desirable features.

Clearly, the choice of current bound rates as the base would mean that some countries would have to make only small, or no, reductions in applied rates. Since WTO negotiations depend on meeting the needs of all participants, the approach to be adopted must meet the needs of participants. At the end of the day, countries will consider whether the reductions in their partners' applied rates, and the increases in the security of their market access, resulting from the chosen base and reduction formula (or other approach) are sufficient to make the resulting package worthwhile.

If the focus continues to be on bound, rather than applied, tariffs, then something will need to be done about the roughly 40 percent of tariffs on industrial products in developing countries that remain unbound. (Again, see Table 1.) One approach to dealing with this problem would be to agree on some basis for establishing tariff bindings on all of these products. The results of the Uruguay Round agreement on agriculture, where 100 percent binding was achieved by means that provided considerable discretion to individual countries suggests that some sort of formula approach might also be desirable in the tariff binding stage. Perhaps such bindings should be established at or below the average rate for tariff bindings on those sectors currently bound, or at a rate specified to be at, or a specific percentage above, current applied rates for the same commodity. Additionally, binding overhang and unbound tariffs might also be addressed by use of recent historic average applied rates.

\subsection{Adding flexibility}

Even with the additional flexibility allowed by the extension of the Swiss formula offered in this paper, there is a risk that it would not be sufficiently general to meet the political constraints of all countries on all products. One way to deal with this problem would be to allow exceptions for particular, sensitive products. Based on GATT history, this approach seems likely to undercut the whole objective of achieving substantial market access gains in the negotiations. In the Kennedy Round, the intent was to minimize exceptions (Baldwin 1986), but the discretion to make exceptions was initially given to individual countries. While the initial lists of exceptions in each country were relatively modest, each country had the right to pull 
back from its original offers if it did not think a balance of concessions had been achieved. A spiraling process of withdrawals from the original offers substantially reduced the tariff cuts achieved. In the Tokyo Round, a much larger number of exceptions was tabled from the beginning, and subsequent withdrawals to achieve a better perceived balance of concessions resulted in many products being excepted from the formula cuts.

One way to deal with this problem of exceptions while allowing additional flexibility would be to make a formula cut first, and to allow for renegotiations with compensation from this new base. This approach shifts the onus in making exceptions from the country to its trading partners, and seems much less likely to lead to fewer and smaller exceptions than the traditional discretionary approaches. Clearly, it would ensure the maintenance of a balance of concessions - the lack of which created such difficulties in the Kennedy and Tokyo Rounds.

While we do not deal explicitly with the value of agricultural tariff-rate-quotas in this paper, reductions in out-of-quota tariffs may need to be associated with expansion of the quotas to help build support from the holders of the quotas. A simple rule might be to expand quotas by the same percent applied to the reduction in the average tariff binding. This approach would help toreduce potential problems associated with reductions in the quota rents received by exporters holding Tariff-Rate-Quotas.

Many other issues would need to be considered in a real-world negotiation. One potentially serious problem is created by specific, mixed and compound tariffs. Topsdown formulas such as the Swiss formula cannot be directly applied to these tariffs, since it is not possible to know which are the high and low tariffs without knowledge of the value of the goods. One option would be to convert all specific tariffs to ad valorem form prior to applying the formula. Another would be to exclude them from application of the formula, and to use a straight percentage cut (linear) for all such tariffs.

Whether the approaches outlined in this section and the previous section have any chance of being acceptable depends heavily on the nature of the distributions of applied tariffs and tariff bindings in member countries. Without knowledge of the distribution of tariffs, it is impossible to tell, for instance, whether specifying a target reduction in average tariffs will result in acceptable changes in peak tariff levels in particular countries or groups of countries. Similarly, it is impossible to know whether reductions based on choice of a tariff ceiling in a Swiss formula will produce reasonable reductions in average tariffs, or whether negotiations based on bindings would produce a coherent pattern of tariff reductions. The set of tables in the next section provides a very brief initial empirical evaluation of the implications of formula approaches for a range of countries, taking into account the current distribution of their tariffs and tariff bindings.

\section{AN EXAMPLE}

A simple, hypothetical analysis can illustrate some of the key implications of the approaches we discuss, including the implications of binding overhang. This is meant to be illustrative and, in particular, does not directly incorporate the requirement for 
less than full reciprocity by developing countries in reduction commitments on nonagricultural products specified in paragraph 16 of the Doha Ministerial Declaration (WTO 2001). The guidelines used for a notional market access package focused on a 50 percent cut in average tariffs can be summarized as follows.

- A target was set for a reduction in average tariff bindings of $50 \%$.

- Unbound tariffs were initially bound at $150 \%$ of applied MFN rates.

- The parameter $b$ was initially set to 1 (the original Swiss formula).

- Agricultural and industrial tariffs were treated separately

- Members could adjust the $a$ and $b$ parameters, as long as

1. $b$ remains at or above 1

2. the average bound tariff falls by $50 \%$ or more

3. other Members agree to the deviation from $b=1$

- Any subsequent renegotiations of tariffs maintain the overall cut in the average tariff

Tables 2, 3 and 4 present the effect of formula-based reductions on the tariff schedules of the EU, Japan, the United States (industrial countries) and Brazil, India, and Thailand (developing countries). In all cases, the basic experiment is a targeted $50 \%$ reduction in average bound tariffs ${ }^{9}$. Table 2 summarizes results under the basic Swiss formula, while Tables 3 and 4 illustrate the effect of added flexibility through the flexibility parameter. These are summarized in Figure 3.

Figure 3

Binding Overhang in INDUSTRY:

the impact of a $\mathbf{5 0} \%$ reduction in bound rate average on applied rate average

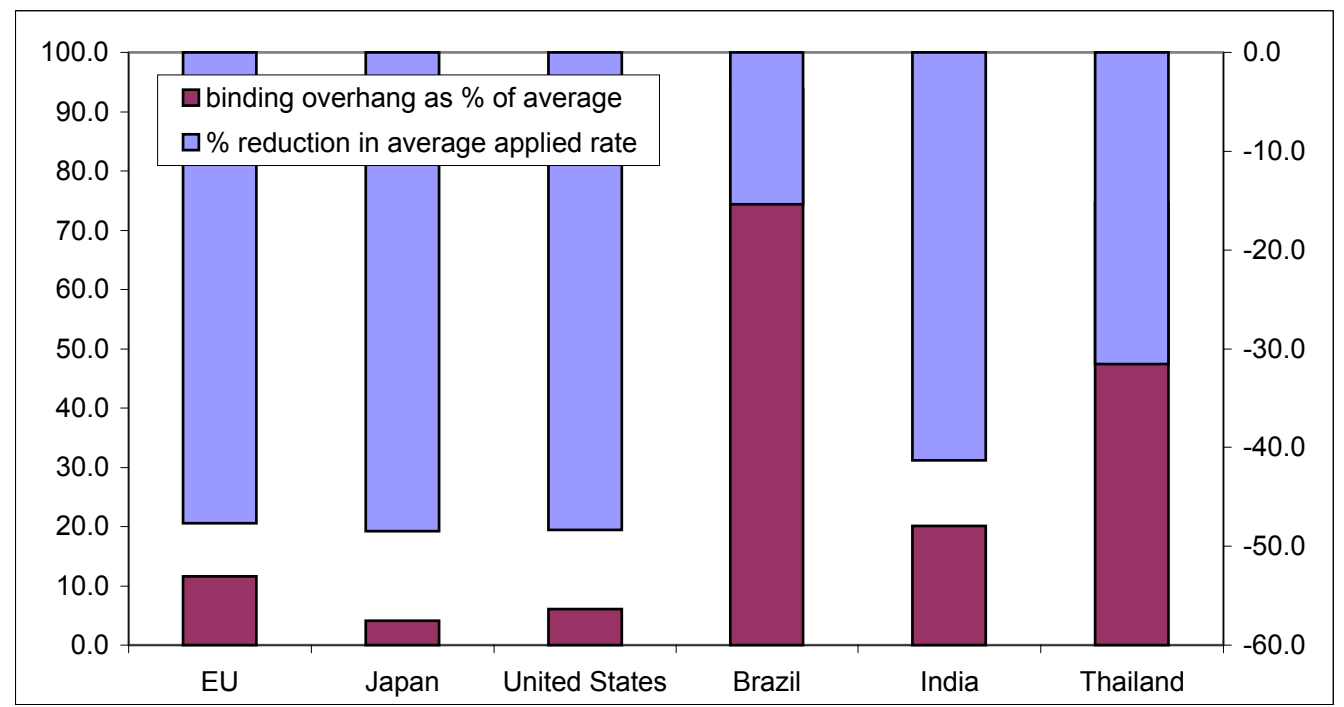

For the United States, bound rates generally are very close to applied rates. This is reflected in low initial binding overhang (the gap between average bound and applied rates shown as a percent of the average applied rate). This also means that all variations in our formula lead to significant cuts, especially at the higher rates. The

\footnotetext{
${ }^{9}$ For reasons of data availability, only ad valorem tariffs are considered.
} 
result is a reduction in maximum rates, variance, and average rates. Notice from Table 3 that peak rates are not reduced as much when the flexibility parameter $b$ is raised above 1 . In particular, while still achieving a 50\% reduction in the average bound rate, the United States would be able to keep its highest ad valorem applied rates on industrial goods in the range from 7.3 to $9.9 \%$, depending on the selection of the $b$ parameter. Similarly, the EU would be able to keep some peak industrial rates at up to four and a half times the average tariff. Even though some notion of peak protection is preserved, peak rates themselves come down, the overall structure is flattened out under all approaches, and therefore tariff escalation is reduced.

Brazil, by contrast, is a country with average bound rates well above applied rates. This is reflected in Table 2, as well as Table 4 and Figure 3. From our analysis, we have found that a $35 \%$ target reduction in average bindings is just enough to reduce some of the peak rates, while leaving most applied rates untouched. With a $50 \%$ reduction in average bindings, Brazil's industrial average applied rate falls by $15.4 \%$. While smaller than the proportional cut in average tariffs in the industrial countries, this translates into a larger percentage reduction in the cost of imports than those observed in the industrial countries. In agriculture, the binding overhang is so great that almost nothing happens to applied rates (a 50\% reduction in bindings yields only a 3.7 percent reduction in applied rates.) However, the binding overhang is reduced sufficiently to ensure real liberalization in subsequent negotiations. We also need to recognize that bindings have value when they limit credible threats to raise tariffs. Based on the past 20 years, Brazil has had episodes of very high tariffs. These new bound rates, being much closer to the applied rates than current bindings, therefore provide more market access security than current bindings.

India realizes a similar (i.e. very small) cut in applied agricultural tariffs, again reflecting high binding overhang in both developed and developing countries. The reduction in the average industrial tariffs is greater than in the case of Brazil. This reduction of 8 percentage points in the average tariff on industrial products implies a much larger reduction in the price of imports than in the case of the industrial countries.

Thailand, with less binding overhang, realizes greater reductions in agricultural tariffs, with these tariffs reduced by over 40 percent relative to their initial average level. In the industrial sector, Thailand's reduction in applied rates is just over 30 percent, which necessitates a reduction in applied tariffs of around 3 percentage points. This generates a reduction in the price of imports that is larger than in the industrial country cases considered.

In agriculture, the problem of binding overhang is much more serious. Even with a large cut, such as the 50 percent cut in bindings considered here, we see only small reductions in applied rates on agricultural goods in Brazil and India. In Thailand, by contrast, we see sharp reductions in agricultural tariffs because of the limited binding overhang in this case. The problem is likely to be even more widespread than these initial results would indicate, because of the prevalence of specific tariffs and other non-ad valorem protection measures not included in the current data set. Even in the industrial countries, it seems likely that there would be problems associated with binding overhang in these commodities. The results indicate, however, that application of a formula approach would result in a significant reduction in binding 
overhang, and at least some reduction in applied rates using an ambitious goal such as a fifty percent reduction in average tariffs. As shown by Francois and Martin (forthcoming), such reductions in binding overhang may have substantial value both to the importing country and to its trading partners.

\section{CONCLUSIONS}

In this paper, we first consider the potential advantages of formula approaches in terms of their ability to generate large reductions in protection and to improve market access (not coincidentally making people better off as well). The fact that they can be used to achieve tops-down reductions in tariffs is seen as particularly important in achieving this objective.

We then examine the key features of the market access landscape that will affect the choice of approaches to negotiations. These features include the large dispersion of average tariffs amongst the active participants in the negotiations, and the large gaps between applied and bound tariff rates in many countries and sectors.

Our review of potential approaches to tariff reduction covers a range of formulas that has been proposed. The Swiss formula approach used in the Tokyo Round is seen as particularly desirable because of its ability to introduce a tariff rate ceiling, and to bring about larger reductions in the highest tariff rates. Unfortunately, it appears likely to be too restrictive to apply it with the same coefficient used in the Tokyo Round, particularly because of the large dispersion in the average and dispersion of initial tariff rates, and the presence of binding overhang in many countries.

To overcome, or at least reduce, this restrictiveness, we explore two new options for consideration, a targeted and a flexible Swiss formula approach. The first is a simple adaptation of the Swiss formula that is targeted to a specific reduction in average tariffs for particular country and commodity groups (eg agricultural and nonagricultural). The second is a more flexible version of the Swiss formula that would allow the same cut in the average tariff to be achieved with somewhat smaller reductions in peak tariffs. Essentially, this increase in flexibility would allow larger cuts in smaller tariff rates to be used to compensate for smaller reductions in higher tariffs. While such a change would almost certainly reduce economic efficiency, it may ultimately be preferable to a retreat into exceptions as a way of reaching a politically-acceptable agreement. This flexible formula approach potentially allows for a Swiss family of formulas, or a Swiss-Army set of instruments, with different tradeoffs between tariff cuts on higher and lower tariff rates.

We examine the potential outcomes of applying this family of formulas in three industrial country markets-Europe, Japan and the United States-and three developing country markets-Brazil, India and Thailand. In the example, we target cuts in average bound tariff rates in each country, considering agricultural and industrial products separately. Preliminary analysis suggests that, in this situation, only a bold cut, such as the 50 percent target used in the Kennedy Round, would make substantial progress in increasing market access in both developing and developed countries. 
In industrial products, we find that a 50 percent cut in average tariff bindings would bring about substantial reductions in average applied rates in each country, while particularly reducing peak tariffs and escalation. While binding overhang reduces the percentage cuts in applied rates in the three developing countries, the resulting fall in the price of imports would still be larger in the three developing countries considered than in the industrial countries.

In agricultural products, binding overhang is greater in many countries than it is for industrial products. Based on the ad valorem tariff rate data used in this initial, exploratory analysis, even a 50 percent reduction in agricultural tariff bindings would produce only a very small reduction in applied tariff rates for India and Brazil. For the industrial countries, and for Thailand, substantial reductions in applied rates would be required. The results highlight the problems resulting created by the binding overhang from the Uruguay Round for obtaining a "balance of concessions" in the current negotiations on agricultural trade reform.

Clearly, a great deal of work is likely before a way forward can be identified that is economically worthwhile, balanced, and politically acceptable. We hope that some of the ideas presented in this paper might prove useful in this difficult and demanding process. 


\section{References}

Abreu, M. (1996), 'Trade in manufactures, the outcome of the Uruguay Round, and developing country interests' in Martin, W. and Winters, L. A. eds The Uruguay Round and the Developing Countries, Cambridge University Press, Cambridge.

Baldwin, R.E. (1986), 'Toward more efficient procedures for multilateral tariff negotiations' Aussenwirtschaft 41, Heft II/III:379-94.

Baldwin, R. E. (1987), 'Multilateral liberalization', in Finger, J. M. and Olechowski, A. eds. The Uruguay Round: a Handbook for the Multilateral Trade Negotiations, World Bank, Washington DC.

Blackhurst, R., A. Enders and J.F. Francois, (1996)"The Uruguay Round and market access: opportunities and challenges for developing countries," in W. Martin and A Winters, eds., The Uruguay Round and Developing Countries, Cambridge University Press, Cambridge.

Francois, J.F., (2001), THE NEXT WTO ROUND: North-South stakes in new market access negotiations, CIES Adelaide and the Tinbergen Institute, CIES: Adelaide, ISBN: 0863964745.

Francois, J.F. and Martin, W. "Commercial policy variability, bindings, and market access," European Economic Review, forthcoming.

Hertel, T. and Martin, W. (2001), 'Liberalizing agriculture and manufactures in a Millennium Round', The World Economy 23:455-70.

Hoekman, B. (2002), 'Strengthening the global trade architecture for development' Policy Research Working Paper 2757, World Bank, Washington DC.

Hoekman, B., Ng, F. and Olarreaga, M. (2002), Eliminating excessive tariffs on exports of least developed countries, Policy Research Working Paper 2604, World Bank, Washington DC.

Hoekman, B. and Olarreaga, M. (2002), Une proposition pour l'OMC: La $<<$ Super $>>$ clause de Nation Plus Favorisée, Mimeo, World Bank, Washington DC.

Josling, T. and Rae, A., (forthcoming), 'Options for enhancing market access in the WTO round', Ch 9 in Ingco, M. and Winters, L.A. eds. Developing Countries, Agriculture, and the WTO, Cambridge University Press, Cambridge.

Laird, S. (1998), 'Multilateral Approaches to Market Access Negotiations," WTOTPRD staff working paper TPRD-98-02, Geneva.

Laird, S. and Yeats, A. (1987), 'Tariff cutting formulas - and complications' in Finger, J. M. and Olechowski, A. eds. The Uruguay Round: a Handbook for the Multilateral Trade Negotiations, World Bank, Washington DC. 
López, R. and Panagariya, A. (1992), 'On the theory of piecemeal tariff reform: the case of pure imported intermediate inputs' American Economic Review 82(3):615-25.

Low, P. and Mattoo, A. (2003), 'Approaches to further liberalization of trade in services', in Martin, W. and Pangestu, M. eds Options for Global Trade Reform, Cambridge University Press, Cambridge.

Martin, W. and Winters, L. A. eds (1996), The Uruguay Round and the Developing Countries, Cambridge University Press, Cambridge.

$\mathrm{Ng}$, F. (2002), 'Tariff rates in average tariff rates for developing and developed countries', http://www1.worldbank.org/wbiep/trade/TR_Data.html

Panagariya, A. (2002), 'Formula approaches to reciprocal tariff liberalization' in Hoekman, B., Mattoo, A. and English, P. eds. Development, Trade and the WTO, World Bank, Washington DC.

Preeg, E. (1970), Traders and Diplomats: an Analysis of the Kennedy Round of Negotiations under the General Agreement of Tariffs and Trade, Brookings Institution, Washington DC.

Preeg, E. (2002), 'Free trade in manufactures as the central objective for the Doha Multilateral trade negotiations', Comments to the Trade Policy Staff Committee, US Trade Representative, www.mapi.net/filepost/freetrade.pdf. .

Stern, R.M. (1976), 'Evaluating alternative formulas for reducing industrial tariffs' Journal of World Trade Law 10:50-64.

Vousden, N. (1990), The Economics of Trade Protection, Cambridge University Press, Cambridge.

World Bank (2001), Global Economic Prospects and the Developing Countries 2001, World Bank, Washington DC.

WTO (2001), 'Ministerial Declaration', Ministerial Conference, Fourth Session, Doha, 9-14 November 2001, WT/MIN(01)/DEC/1, World Trade Organization, Geneva. 
Table 1

Industrial tariff rates and bindings -- post UR and ITA

\begin{tabular}{|c|c|c|c|c|c|c|}
\hline & \multicolumn{4}{|c|}{ Percent of MFN imports that are subject to: } & \multicolumn{2}{|l|}{ Tariff lines } \\
\hline & bound tariffs & unbound tariffs & $\begin{array}{l}\text { tariffs bound } \\
\text { above applied } \\
\text { rates }\end{array}$ & $\begin{array}{c}\text { tariffs unbound } \\
\text { or bound above } \\
\text { applied rates }\end{array}$ & $\begin{array}{c}\text { Share of bound } \\
\text { duty free tariff } \\
\text { lines to total } \\
\text { tar. lines }\end{array}$ & $\begin{array}{l}\text { Total tariff } \\
\text { lines }\end{array}$ \\
\hline Argentina & 100.0 & 0.0 & 99.9 & 99.9 & 0.0 & 10530 \\
\hline Australia & 96.9 & 3.1 & 31.7 & 34.8 & 17.7 & 5520 \\
\hline Brazil & 100.0 & 0.0 & 91.0 & 91.0 & 0.5 & 10860 \\
\hline Canada & 99.8 & 0.2 & 45.7 & 45.9 & 34.5 & 6261 \\
\hline Chile & 100.0 & 0.0 & 99.7 & 99.7 & 0.0 & 5055 \\
\hline Colombia & 100.0 & 0.0 & 97.7 & 97.7 & 0.0 & 6145 \\
\hline El Salvador & 97.1 & 2.9 & 96.0 & 98.9 & 0.0 & 4922 \\
\hline European Union & 100.0 & 0.0 & 17.7 & 17.7 & 26.9 & 7635 \\
\hline Hungary & 93.6 & 6.4 & 3.3 & 9.7 & 10.4 & 5896 \\
\hline India & 69.3 & 30.7 & 14.8 & 45.5 & 0.0 & 4354 \\
\hline Indonesia & 92.3 & 7.7 & 86.6 & 94.3 & 0.0 & 7735 \\
\hline Japan & 95.9 & 4.1 & 0.1 & 4.2 & 47.4 & 7339 \\
\hline Korea & 89.8 & 10.2 & 3.4 & 13.6 & 11.6 & 8882 \\
\hline Malaysia & 79.3 & 20.7 & 31.0 & 51.7 & 1.6 & 10832 \\
\hline Mexico & 100.0 & 0.0 & 98.4 & 98.4 & 0.0 & 11255 \\
\hline New Zealand & 100.0 & 0.0 & 46.5 & 46.5 & 39.5 & 5894 \\
\hline Norway & 100.0 & 0.0 & 36.5 & 36.5 & 46.6 & 5326 \\
\hline Peru & 100.0 & 0.0 & 98.5 & 98.5 & 0.0 & 4545 \\
\hline Phillipines & 67.4 & 32.6 & 15.5 & 48.1 & 0.0 & 5387 \\
\hline Poland & 92.8 & 7.2 & 44.6 & 51.8 & 2.2 & 4354 \\
\hline Singapore & 36.5 & 63.5 & 11.7 & 75.2 & 15.2 & 4963 \\
\hline Sri Lanka & 9.2 & 90.8 & 1.4 & 92.2 & 0.1 & 5933 \\
\hline Thailand & 67.4 & 32.6 & 8.9 & 41.5 & 0.0 & 5244 \\
\hline Tunisia & 67.9 & 32.1 & 41.5 & 73.6 & 0.0 & 5087 \\
\hline Turkey & 49.3 & 50.7 & 0.0 & 50.7 & 1.4 & 15479 \\
\hline United States & 100.0 & 0.0 & 14.0 & 14.0 & 39.4 & 7872 \\
\hline Uruguay & 100.0 & 0.0 & 96.3 & 96.3 & 0.0 & 10530 \\
\hline Venezuela & 100.0 & 0.0 & 90.3 & 90.3 & 0.0 & 5974 \\
\hline Zimbabwe & 13.6 & 86.4 & 3.9 & 90.3 & 3.0 & 1929 \\
\hline $\begin{array}{l}\text { source: Francois } \\
\text { Agreement sched }\end{array}$ & based on WTO & d World Bank & ta on Uruguay & Round and post & Information $\mathrm{Te}$ & \\
\hline
\end{tabular}


Table 2

Summary of Effects of Basic Swiss Formula Reductions

Applied tariffs before and after a $\mathbf{5 0} \%$ cut in average tariff bindings

Agriculture

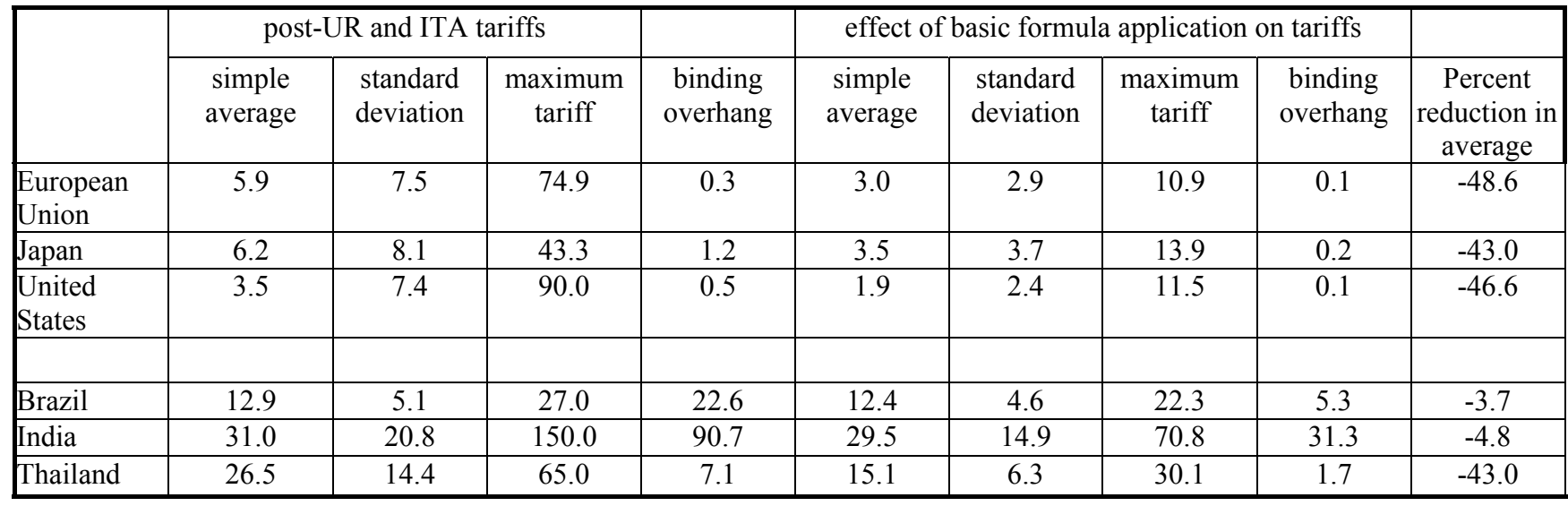

Non-agriculture

\begin{tabular}{|c|c|c|c|c|c|c|c|c|c|}
\hline & \multicolumn{3}{|c|}{ post-UR and ITA tariffs } & \multirow[b]{2}{*}{$\begin{array}{l}\text { binding } \\
\text { overhang }\end{array}$} & \multicolumn{4}{|c|}{ effect of basic formula application on tariffs } & \multirow[b]{2}{*}{$\begin{array}{c}\text { Percent } \\
\text { reduction in } \\
\text { average }\end{array}$} \\
\hline & $\begin{array}{c}\text { simple } \\
\text { average }\end{array}$ & $\begin{array}{c}\text { standard } \\
\text { deviation }\end{array}$ & $\begin{array}{l}\text { maximum } \\
\text { tariff }\end{array}$ & & $\begin{array}{c}\text { simple } \\
\text { average }\end{array}$ & $\begin{array}{l}\text { standard } \\
\text { deviation }\end{array}$ & $\begin{array}{c}\text { maximum } \\
\text { tariff }\end{array}$ & $\begin{array}{l}\text { binding } \\
\text { overhang }\end{array}$ & \\
\hline $\begin{array}{l}\text { European } \\
\text { Union }\end{array}$ & 3.7 & 3.6 & 17.0 & 0.4 & 1.9 & 1.4 & 5.0 & 0.1 & -47.7 \\
\hline Japan & 2.3 & 3.4 & 30.9 & 0.1 & 1.2 & 1.4 & 5.6 & 0.0 & -48.5 \\
\hline $\begin{array}{l}\text { United } \\
\text { States }\end{array}$ & 3.2 & 4.3 & 37.5 & 0.2 & 1.7 & 1.6 & 6.1 & 0.0 & -48.3 \\
\hline Brazil & 15.9 & 6.0 & 35.0 & 14.9 & 13.5 & 4.2 & 16.7 & 1.9 & -15.4 \\
\hline India & 19.2 & 16.5 & 40.0 & 3.9 & 11.3 & 9.2 & 30.5 & 0.3 & -41.3 \\
\hline Thailand & 10.5 & 10.8 & 80.0 & 7.8 & 7.2 & 6.1 & 20.7 & 2.0 & -31.6 \\
\hline
\end{tabular}


Table 3

EU, Japan, and US: Effects of a 50\% Reduction in Average Bound Rates

\begin{tabular}{l} 
EUROPEAN UNION \\
\hline
\end{tabular}

\begin{tabular}{|c|c|c|c|c|c|c|c|}
\hline \multicolumn{8}{|l|}{ JAPAN } \\
\hline & "a" parameter & $\begin{array}{l}\text { compen-sation } \\
\text { (b) parameter }\end{array}$ & $\mid \begin{array}{l}\text { simple average } \\
\text { tariff (percent) }\end{array}$ & standard error & $\begin{array}{c}\text { maximum } \\
\text { tariff (percent) }\end{array}$ & $\begin{array}{c}\text { simple average } \\
\text { binding } \\
\text { overhang (pct } \\
\text { points) }\end{array}$ & $\begin{array}{c}\text { Percent } \\
\text { reduction in } \\
\text { average tariff }\end{array}$ \\
\hline$* A g$ & 1 & 0 & 6.2 & 8.1 & 43.3 & 1.2 & N/A \\
\hline *Non-Ag & 1 & 0 & 2.3 & 3.4 & 30.9 & 0.1 & $\mathrm{~N} / \mathrm{A}$ \\
\hline $\mathrm{Ag}$ & 17.1 & 1.0 & 3.5 & 3.7 & 13.9 & 0.2 & -43.0 \\
\hline Non-Ag & 6.3 & 1.0 & 1.2 & 1.4 & 5.6 & 0.0 & -48.5 \\
\hline $\mathrm{Ag}$ & 22.7 & 1.2 & 3.5 & 3.9 & 16.6 & 0.2 & -43.2 \\
\hline Non-Ag & 8.1 & 1.2 & 1.2 & 1.5 & 6.8 & 0.0 & -48.4 \\
\hline $\mathrm{Ag}$ & 39.6 & 1.5 & 3.5 & 4.2 & 21.3 & 0.2 & -43.7 \\
\hline Non-Ag & 13.9 & 1.5 & 1.2 & 1.6 & 9.7 & 0.0 & -48.4 \\
\hline Percent of & industrial t & ariff lines c & currently un & bound: & $0.84 \%$ & & \\
\hline $\begin{array}{l}\text { *note: a: } 1, \mathrm{~b} \\
\text { Uruguay Ro }\end{array}$ & $\begin{array}{l}: 0 \text { correspond } \\
\text { ind (or base) }\end{array}$ & $\begin{array}{l}\text { ds to zero cut } \\
\text { rates of tariff }\end{array}$ & $\begin{array}{l}\text { s. The first tw } \\
\text { fs. }\end{array}$ & vo rows there & efore represen & th post- & \\
\hline $\begin{array}{l}\text { Also, agricu } \\
\text { applied to ex }\end{array}$ & $\begin{array}{l}\text { ture tariffs ar } \\
\text { cluded tariff }\end{array}$ & e limited to $a$ & $\begin{array}{l}\text { ad valorem tari } \\
\text { ly at higher } a d\end{array}$ & iffs. Other sp & pecific tariffs & may be & \\
\hline
\end{tabular}


Table 3 - continued

\begin{tabular}{l}
\hline UNITED STATES \\
\hline
\end{tabular}


Table 4

Brazil, India, Thailand: Effects of a $50 \%$ Reduction in Average Bound Rates

BRAZIL

\begin{tabular}{|l|c|c|c|c|c|c|c|}
\hline & "a" parameter compen-sation & $\begin{array}{c}\text { cimple average } \\
\text { (b) parameter }\end{array}$ & tariff (percent) & & & & \\
\hline *Ag & 1 & 0 & 12.9 & 5.1 & 27.0 & 22.6 & N/A \\
\hline *Non-Ag & 1 & 0 & 15.9 & 6.0 & 35.0 & 14.9 & N/A \\
\hline & & & & & & & \\
\hline $\mathrm{Ag}$ & 37.4 & 1 & 12.4 & 4.6 & 22.3 & 5.3 & -3.7 \\
\hline Non-Ag & 31.8 & 1 & 13.5 & 4.2 & 16.7 & 1.9 & -15.4 \\
\hline & & & & & & & \\
\hline $\mathrm{Ag}$ & 47.0 & 1.2 & 12.4 & 4.6 & 23.2 & 5.3 & -4.0 \\
\hline Non- $\mathrm{Ag}$ & 39.8 & 1.2 & 13.5 & 4.3 & 16.8 & 1.9 & -15.3 \\
\hline & & & & & & & \\
\hline $\mathrm{Ag}$ & 75.8 & 1.5 & 12.3 & 4.6 & 24.7 & 5.4 & -4.5 \\
\hline Non- $\mathrm{Ag}$ & 64.3 & 1.5 & 13.5 & 4.4 & 17.1 & 1.9 & -15.1 \\
\hline
\end{tabular}

Percent of industrial tariff lines currently unbound: $\quad 0 \%$

*note: $a: 1, b: 0$ corresponds to zero cuts. The first two rows therefore represent post-

Uruguay Round (or base) rates of tariffs.

Also, agriculture tariffs are limited to ad valorem tariffs. Other specific tariffs may be

applied to excluded tariff lines, typically at higher ad valorem rates than averages shown.

\begin{tabular}{l}
\hline INDIA \\
\hline
\end{tabular}


Table 4 -- continued

\begin{tabular}{|c|c|c|c|c|c|c|c|}
\hline \multicolumn{8}{|c|}{ THAILAND } \\
\hline & "a" parameter & $\begin{array}{l}\mathbf{r} \mid \text { compen-sation } \\
\text { (b) parameter }\end{array}$ & $\begin{array}{l}\text { simple average } \\
\text { tariff (percent) }\end{array}$ & standard error & $\begin{array}{c}\text { maximum } \\
\text { tariff (percent) }\end{array}$ & $\mid \begin{array}{c}\text { simple average } \\
\text { binding } \\
\text { overhang (pct } \\
\text { points) }\end{array}$ & $\begin{array}{c}\text { Percent } \\
\text { reduction in } \\
\text { average tariff }\end{array}$ \\
\hline *Ag & 1 & 0 & 26.5 & 14.4 & 65.0 & 7.1 & $\mathrm{~N} / \mathrm{A}$ \\
\hline *Non-Ag & 1 & 0 & 10.5 & 10.8 & 80.0 & 7.8 & N/A \\
\hline Ag & 38.2 & 1.0 & 15.1 & 6.3 & 30.1 & 1.7 & -43.0 \\
\hline Non-Ag & 27.8 & 1.0 & 7.2 & 6.1 & 20.7 & 2.0 & -31.6 \\
\hline $\mathrm{Ag}$ & 48.9 & 1.2 & 15.1 & 6.6 & 34.6 & 1.7 & -42.9 \\
\hline Non-Ag & 35.0 & 1.2 & 7.2 & 6.1 & 23.0 & 2.0 & -31.4 \\
\hline $\mathrm{Ag}$ & 81.5 & 1.5 & 15.1 & 7.2 & 43.8 & 1.7 & -42.9 \\
\hline Non-Ag & 56.5 & 1.5 & 7.2 & 6.2 & 27.4 & 1.9 & -31.1 \\
\hline \multicolumn{6}{|c|}{ Percent of industrial tariff lines currently unbound: } & \multicolumn{2}{|l|}{$32 \%$} \\
\hline \multicolumn{8}{|c|}{$\begin{array}{l}\text { *note: } a: 1, b: 0 \text { corresponds to zero cuts. The first two rows therefore represent post- } \\
\text { Uruguay Round (or base) rates of tariffs. } \\
\text { Also, agriculture tariffs are limited to } a d \text { valorem tariffs. Other specific tariffs may be } \\
\text { applied to excluded tariff lines, typically at higher } a d \text { valorem rates than averages } \\
\text { shown. }\end{array}$} \\
\hline
\end{tabular}




\section{Appendix}

\section{Impacts of Different Formulas on the Price of Imports}

The change in the price of imports for any given tariff change depends on the change in the power of the tariff $T=t /(1+t)$. In a small country, the change in $T$ exactly determines the price impact while, in a large country, it is also influenced by the impact of the tariff change on world prices. Whether a formula results in rising or falling proportional reductions in the domestic prices of imported goods is determined by the derivative of $T$ with respect to $t_{0}$.

\section{Proportional Cuts}

For the proportional cut formula, it may be useful todefine the market access concession $\mu$ as follows:

$$
\begin{aligned}
& \mu=\frac{\Delta t}{1+t_{0}}=\frac{(1-c) t_{0}}{1+t_{0}}=\frac{(1-c)}{t_{0}^{-1}+1} \\
& \frac{d \mu}{d t_{0}}=\frac{(1-c)}{\left(1+t_{0}\right)^{2}}>0
\end{aligned}
$$

The derivative makes clear that the proportional price reduction increases with the initial tariff level using the proportional cut approach.

\section{Linear Reduction Formula}

This approach has the desirable feature that the percentage cuts in tariffs increase with the intial tariff rate. As can be send from equation A.2, the ratio $t_{1} / t_{0}$ falls as $t_{0}$ rises, implying larger percentage tariff cuts as the initial tariff level rises.

$$
\frac{t_{1}}{t_{0}}=\frac{d}{t_{0}}+f
$$

We can estimate the impact on domestic prices in a similar manner to that done for the proportional cut approach above:

$$
\begin{aligned}
& \mu=\frac{-\Delta t}{1+t_{0}}=-\frac{d+(f-1) t_{0}}{1+t_{0}}=\frac{-d}{1+t_{0}}+\frac{-(f-1)}{t_{0}^{-1}+1} \\
& \frac{d \mu}{d t_{0}}=\frac{d}{\left(1+t_{0}\right)^{2}}-\frac{(f-1)}{\left(t_{0}^{-1}+1\right)^{2}} t_{0}^{-2}>0
\end{aligned}
$$

\section{Swiss Formula}

The progressive nature of the reductions under the Swiss formula can be shown by the ratio of the new to the old tariff: 


$$
\frac{t_{1}}{t_{0}}=\frac{a}{a+t_{0}}
$$

If we examine equation (6) it is clear that, as $t_{0}$ increases, the ratio $t_{1} / t_{0}$ declines, implying that the higher initial tariff rates are subject to larger percentage reductions. Like the other approaches discussed above, the Swiss-formula also yields market access concessions that are greater for high tariff products than low-tariff products. Formally, we have:

$$
\begin{aligned}
& \mu=\frac{-\Delta t}{1+t_{0}}=-\frac{\frac{a t_{0}}{a+t_{0}}-t_{0}}{1+t_{0}}=-t_{0}\left(\frac{a}{\left(1+t_{0}\right)\left(a+t_{0}\right)}-\frac{1}{1+t_{0}}\right) \\
& \frac{d \mu}{d t_{0}}=\frac{t_{0}\left(2 a+a t_{0}+t_{0}\right)}{\left(a+t_{0}\right)^{2}\left(1+t_{0}\right)^{2}}>0
\end{aligned}
$$

